\title{
Green Buildings in the Arctic region: a literature review
}

\author{
Lucrezia Ravasio ${ }^{1}$, Raymond Riise ${ }^{1}$, and Svein Erik Sveen ${ }^{1}$ \\ ${ }^{1}$ UiT The Arctic University of Norway, Department of Building, Energy and Material Technology, 8515 Narvik, Norway
}

\begin{abstract}
Green Buildings are defined as environmental-friendly buildings aimed at minimizing the impact on the natural environment through a sustainable and efficient use of resources over their life-cycle. This is, perhaps, a recently-introduced building concept that is increasingly gaining attention due to the policies and strategies intended to reduce the carbon footprint of conventional buildings, which nowadays represent a large portion of the global energy consumption and $\mathrm{C} 02$ emissions. This study provides a systematic literature review of the existing body of knowledge of research related to Green Buildings in the arctic region. Despite numerous studies and projects developed during the last decades, a study describing the current research for this specific region is still missing. Starting from the definition of Green Building and Arctic Region, an examination is made of research approaches developed to achieve the required green building standards, for which rating tools currently in use for their evaluation are also identified. The result is a critical analysis highlighting benefits and critical issues of Green Buildings located in the Arctic in comparison with conventional buildings, focusing on the environmental, economic and social dimensions. Finally, future research opportunities are presented and discussed.
\end{abstract}

\section{Introduction}

In more recent decades, a growing consciousness has become apparent of the impact of human activities on the natural environment as affected by the construction industry, and for which the link between sustainability and buildings has been highlighted thereby giving this growing awareness both strength and momentum [1]. The green movement, having spread in all fields of society, has led to the emergence of worldwide national and local programs advancing the green principle in both the construction and home-building sectors [2]. Indeed, studies show that buildings play a significant role in climate change. According to the Global Status Report of 2019 [3], building and construction together account for $36 \%$ of global energy use and $39 \%$ of energy-related carbon dioxide emissions in 2018, which in fact, severely contribute to global warming. The same report declares that, due to the strong floor area and population expansions, total global energy consumption in buildings in 2018 increased 1\% from 2017. In this perspective, Green Buildings become a potential strategy and investment to limit demand and reduce energy intensity.

A Green Building is defined as a high-performance building with a reduced negative impact on the natural environment and human health [4]. This is achieved by applying measures that take into account the building location, as well as water, energy and material use efficiency, resource conservation, indoor air quality, building operation and maintenance over the entire building life-cycle $[2,3]$. Green Buildings also provide benefits from the economic and social perspective, through lower building life-cycle costs and the improved comfort and well-being of their occupants [5]. This promising solution is also expressed in different building concepts related to sustainable and environmental design such as net and nearly zero-energy buildings, zeroemission, zero-carbon and carbon- neutral buildings [6].

The term Climate Change generally refers to the longterm shift in global or local climate patterns, usually identified with the rise of average temperature over the years, due to human activities. Among all the regions of the planet, the Arctic is experiencing the most severe effect of climate change through greater and more rapid rise of average temperature [7]. The Arctic Region is represented by that area north of the Arctic Circle characterized by extreme seasonality and variation in temperature and precipitation, strong gradient in latitude solar and UV radiation [8]. The low temperatures lead to an extensive and permanently ice-covered or frozen ground, i.e. permafrost, which makes the region more vulnerable to climate change. The warming of the Arctic and the consequent melting has global implications, such as alteration of the global ocean circulation, sea level rise and release of methane and carbon dioxide trapped in the permafrost, gases that are feeding and accelerating the process of temperature-rise [9].

In view of these elements, policies aimed at safeguarding and protecting the arctic environment represent a challenge of paramount importance for the

\footnotetext{
* Corresponding author: 1.ravasio@uit.no
} 
region at the present and for the future [10]. Governments with territories in the Arctic - Norway, Sweden, Finland, Denmark, Iceland, Russia, Canada and United States - are closely involved in the development of new initiatives both locally, with national legislation, and globally, with the Arctic Council. Established in 1996 with the Ottawa Declaration, the Arctic Council is an intergovernmental forum promoting cooperation, coordination and interaction among the Arctic States. The Arctic Cooperation includes also the European Union, the Nordic Cooperation, the Barents Cooperation and the United Nations [10].

The purpose of this research is to investigate the local and global initiatives stated by the institutions and the bodies concerned with the reduction of building's carbon footprint in the Arctic. The aim is to examine not only how policies affect the development of Green Buildings in cold regions, but also evaluate the applicability of currently used assessment tools in these special climate conditions. By pointing out the strengths and criticality of Green Buildings, the study permits highlighting future research opportunities in the Arctic.

\section{Sustainable buildings and construction policies}

According to the Paris Agreement, by 2020 countries are asked to communicate their new or updated nationally determined contributions (NDCs) delineating their efforts to reduce national emissions and adapt to the impacts of climate change. For this reason, this section focuses on the medium and long-term strategies developed by arctic governments for the housing and building sector of the High North. The purpose of this review is to analyse the relationship between policies for the Arctic and building legislation at a national level focused on the decarbonisation of the building stock and improvement of energy performance, to permit highlighting the role of such legislation in the Green Building growth-process.

The following subsections present a brief synthesis of national strategies for the Arctic and for the building sector for the following Arctic Countries: Norway, Sweden, Finland, Russia and Canada. Iceland, Greenland and Alaska have been excluded from the discussion because building emissions are not considered to significantly affect climate conditions due to the limited population living in these arctic territories. Data relating to national strategies have been extracted from the Official Publication Channels of the respective Governments.

\subsection{National Strategies}

\subsubsection{Norway}

The development of the High North has been a priority in the Norwegian Government's agenda since 2005, demonstrated by several proposals released over the years. Among them, "New Building Blocks for the High North" and "Norway's Arctic Strategies between geopolitics and social development" are the most significant ones. The first program, established in 2006 and released in 2009, contains 22 specific action points enclosed in seven prioritized areas ranging from technical to humanity. The purpose of the project is to enhance knowledge in and about the north, increasing government activity and presence in the area and lay foundations for sustainable economic and social development in the Arctic regions[12]. The second program, presented in 2017, reveals the government's vision for economic, environmental and social sustainability in the arctic, highlighting the need to reduce greenhouse gas emissions and pollution through promotion and transition to green transport, energy and construction. [13]. However, both plans, released in unified manner on a national level, lack strategies strictly related to the building sector. In particular, in addition to the national building code, the government released the program "Building for the future - environmental action plan for the housing and building sector 2009-2012". It states long-term initiatives for reducing the carbon footprint of buildings, acting on their energy needs and waste production [14]. In fact, according to the "Norwegian Climate Policy 2011-2012", and in line with the broad political climate agreements, Norway aims to achieve emission reductions abroad equivalent to Norwegian emissions in 2030, and carbon neutrality in 2050. Moreover, to implement a climatefriendly building sector, the national building code was revised in 2007, by defining new standards for energy efficiency in and energy supply of buildings [15]. Afterwards, these requirements have been tightened to Passive House standards and nearly-zero Energy Building standards in 2020 .

\subsubsection{Sweden}

The Swedish Government's strategy for the Arctic was presented in 2014 through the "Sweden's strategy for the Arctic region" program, for which priorities and the outlook for Sweden's arctic policy have been outlined. The government's goal is to promote sustainable development in an economic, social and environmental dimension, and to reduce global emissions of greenhouse gases and short-lived climate forces, along with the implementation of the Arctic cooperation program [11]. As in Norway, this strategy focuses only indirectly on the needs of the building sector, since related policies, such as The Planning and Building Act (2010:900) and the Planning and Building Ordinance (2011:338), have been developed by another jurisdiction [16]. Strategic plans for the reduction of climate impacts of buildings are presented in the report: "Sweden's Seventh National Communication on Climate Change", which also include Sweden's climate goal of net zero greenhouses gas emissions by 2045 . The measures involve action on a regional and local level and include a new energy labelling directive (Ecodesign Act SFS 2008:112), and as well, requirements for setting minimum energy performance standards, (Energy Performance of Building Directive 2010/31/EC), and the implementation of a law 
on energy performance certificates for buildings (Energy Performance Certificate Act SFS 2006:985) [17].

\subsubsection{Finland}

In October 2012, the Finnish Government adopted an updated artic policy, extensively summarized in the report "Finland Strategies for the Arctic Region 2013" [18]. The main objectives of the arctic policy are related to the promotion of stability, national and international cooperation and sustainable development [18]. The program also examines possibilities to promote and achieve them, but a specific action for reviewing and redefining the role of buildings for the Arctic is not covered. The document "Government Action Plan 20172019" [19] illustrates mid-term national objectives and activities for the building sector through five strategic priorities and 26 key projects. Priority number $4-$ Bioeconomy and Clean Solution - reveals Finland's interest in introducing and exporting of sustainable solutions to achieve the climate objectives of reducing greenhouse gases and the economical state of the country in the Baltic Sea [19]. This general statement includes also the building sector, whose priorities are identified in the "Energy and Climate Roadmap 2050", a strategic level guide to permit attaining Finland's long-term objective of a carbon-neutral society [20]. Concerning buildings and constructions, the program outlines the necessity of new buildings to meet nearly-zero energy standards by the end of 2020. For renovation, or retrofit, construction projects, the necessity of meeting stricter energy efficiency requirements as set out by the updated national building code of 2013, is emphasised [20].

\subsubsection{Russia}

In 2008, the Russian Federation defined its state policy the national interest for the Arctic to be achieved by the end of 2020. Primary goals include promotion of social and economic development, peace and cooperation, protection of the ecosystem, and a shipping route through the Northeast Passage [11]. Even though the strategy lacks direct or indirect measures for reducing the carbon footprint of buildings in the Artic, national building legislation is continuously evolving. To meet EE (Energy Efficiency) standards, the Government implemented rules for determining energy efficiency class of apartment buildings (Order if the Ministry of Russia n.339/pr of 6 June 2016), and the requirements for energy efficiency of building, structures and facilities (Order if the Ministry of Russia n.1550/pr of 17 November 2017). In 2016, it also released a "Road Map for EE buildings and structures" (Russian Federation Government Order N.1853-R of September 12016 ), in which are emphasized the primary objectives for the housing sector, such as the: rational use of energy resources, increase of high-energy efficiency in design and construction of buildings, and; development of technical regulation and standardization in EE. In addition to new energy efficiency standards, in 2017 the government set several mandatory technical requirements regarding measuring energy consumption in new dwellings and the implementation of requirements for building envelopes. Russia's most recent plan for the building sector aims at modernizing building and production, and increasing the contribution of the technological factor in reducing the energy consumption for the Gross National Product (GDP) by at least $1.5 \%$ per year [21].

\subsubsection{Canada}

In September 2019, the Canadian government released an updated "Arctic and Northern Policy Framework", for which three key opportunities have been highlighted for the circumpolar Arctic region: strengthening the rulebased international order in the Arctic; defining Canada's Arctic boundaries, and finally; broadening Canada's international engagement and contribution to the priorities of Canada's Arctic and North [22]. Even though Canada's arctic policy is mostly focused on international cooperation and on local communities, the government is committed to climate action policy directed at the building sector. Canada's strategy for climate change considers the more-emissions-productive sources. Among them, homes and buildings account for $11 \%$ of Canada's total emissions. The government's long-term solution is to create a low-carbon building sector, ensuring high quality standards through the development of new building codes. The first one is a "net-zero energy ready" model building code for new buildings. The second one is a model code for existing buildings to guide the process of retrofitting buildings to accommodate energy efficiency improvements during renovations [23]. Moreover, the government aims to support home and building retrofit programs across Canada, and improving energy efficiency of historical buildings as well as building located in indigenous communities' [24].

\subsection{Section Summary}

This review has shown that efforts of a number of governments having interests in the Arctic Region are, generally, promoting sustainable economic and social development, international cooperation, and protection of the natural environment in this area. However, specific policies concerning requirements for buildings located in the Arctic are still missing. Nevertheless, due to the Paris Agreement and other international commitments, these countries are linked by similar climate policies, for which stricter requirements are being set for the energy efficiency and usage of buildings. These activities are positive for the development and establishment of lowenergy buildings because they encourage the evolution of national legislation and building codes to curb future energy demand and emissions.

\section{Green Building Rating Systems}

A building is rated green if it satisfies a set of energy performance targets. Over the years, Green Building 
Councils around the world have developed and administered many of the assessment tools aimed at evaluating and identifying buildings that meet green standards and performance requirements. By encouraging and rewarding companies and organizations operating in a green mind-set, these rating systems have become powerful tools that are transforming and pushing the boundaries of sustainability in the building sector. Indeed, they are setting standards in the market place that affect and evolve both the building codes and building related government legislation [25].

Assessment tools can be applied to different types of constructions (e.g. residential or commercial buildings or whole neighbourhoods), during different life-cycle stages (e.g. planning and design, construction, operation and maintenance, renovation or demolition), and using different approaches. All rating systems have a broadly similar structure. They are typically divided into categories covering various aspects of sustainability, to which it is possible to assign a certain value or number of credits. Each category has a different weighted contribution to the overall score.

However, despite similarities, Governments and organizations have developed and suggested the use of systems that comply with local climate conditions, legislation and needs [26]. The following provides a brief overview of perhaps the most well recognized rating tools.

\subsection{LEED and BREEAM}

Currently, worldwide, the leading green building assessment tools are Leadership in Energy and Environmental Design (LEED) and Building Research Establishment's Environmental Assessment Method (BREEAM).

The U.S Green Building Council released the first version of LEED in 1998. It offers certifications for different types of projects, such as New Construction (LEED-NC), Core and Shell (LEED-CS), Commercial Interiors (LEED-CI) and Existing Buildings (LEED-EB), that makes it versatile and capable of reaching a wide audience. In the assessment process, seven parameters are evaluated: Sustainable Sites; Water Efficiency; Energy and Atmosphere; Materials and Resource; Indoor Environmental Quality; Innovation in Design and Regional Priorities. These categories have a maximum achievable number of points and from one to three prerequisites. The base score is 100 , to which 6 and 4 points are added for the Innovation and Design and Regional Priority categories. According to the score achieved, the ranking is divided in four levels: Certified (40-49 points); Silver (50-59 points); Gold (60-79 points); and Platinum (80-110 points) [27]. LEED is currently at its fourth version.

BREEAM is a rating tool developed by Building Research Establishment in UK, launched in 1990. It assesses the environmental impact of newly constructed buildings at the Design Stage (DS) or at the Post Construction Stage (PCS). It is usually divided in ten sections; Management; Health and Wellbeing; Water;
Materials; Energy; Waste; Transport; Land Use; and Ecology; Innovation; Pollution; with an associated score and weight depending on the country being considered. BREEAM also set minimum standards of performance in key areas. Based on the number of credits achieved, the final score is calculated and rated in five levels: Pass $(\geq$ $30 \%$ ); Good ( $\geq 45 \%)$; Very Good $(\geq 55 \%)$; Excellent; ( $\geq 70 \%)$; and Outstanding ( $\geq 85 \%)$ [28].

\subsection{Other Green Buildings Assessment Tools}

Besides LEED and BREEAM, Arctic governments and organizations are currently certifying with the use of other tools, by taking into account specific local climate conditions, economic development level and geographical characteristics. Table 1 shows the most common evaluation systems for each arctic country, along with the total number of certifications and the number of certifications released in the Arctic by each organization. Data regarding certified buildings have been obtained from the official website rating system organizations. A brief description of the system introduced in Table 1 is provided below.

BREEAM-NO and BREEAM-SE, respectively are the Norwegian and the Swedish versions of the certification system. The evaluation is performed according to the same criteria, but with different associated weighting values [29, 30]. However, Miljöbyggnad is Sweden's leading environmental certification system for buildings, since it is based on Swedish building regulations and regulatory requirements. It is used to certify new constructions, refurbished buildings or existing buildings through the evaluation of four areas: Energy; Indoor Environment; Building Material; and Special Environmental Requirements. It has four rating levels: Rated; Bronze; Silver; and Gold [31].

In Finland, the new RTS environmental classification system (RTS GLT) has also been designed in respect of Finnish conditions, legislation and diversity of the country's building stock. It is based on European Standards (CEN TC 350 standards), together with the common best practices in the sector. It evaluates five main areas: Process; Finances; Environment and Energy; Indoor Air and Health; Innovations. The final ranking is given in stars and determined by the total score achieved: 1 star ( $\geq 25$ points); 2 stars ( $\geq 40$ points); 3 stars $(\geq 55$ points); 4 stars ( $\geq 70$ points); 5 stars ( $\geq 85$ points) [32].

Information regarding Russian rating systems are not easily traceable, since most of the information is in Russian. The review has found that in addition to BREEAM and LEED, green buildings are commonly certificated through GOST R, Green Standards Certification System or Green Zoom. GOST R 549542012 is a voluntary national quality standard for construction, that includes several features of a certification system. It is based on requirements on environmental performance provided by Russian legislation and the national building code. It differs to other approaches by not assigning a final ranking or award. The Green Standards Certification System also uses the existing Russian building code and legislation as 
Table 1. Popular Green Building rating tools and certified buildings in Arctic countries

\begin{tabular}{|c|c|c|c|c|c|}
\hline Country & Rating System & $\begin{array}{c}\text { Total } \\
\text { Certifications }\end{array}$ & $\begin{array}{c}\text { Arctic } \\
\text { Certifications }\end{array}$ & Arctic Certified Buildings & Score \\
\hline \multirow{5}{*}{ Norway } & \multirow{4}{*}{ BREEAM-NO } & \multirow{4}{*}{304} & \multirow{4}{*}{4} & $\begin{array}{c}\text { Kontrobygg Statoil Harstad - } \\
\text { Harstad }\end{array}$ & $59.1 \%$ \\
\hline & & & & Bodø 360 - Bodø & $45.6 \%$ \\
\hline & & & & Central Atrium - Bodø & $32.9 \%$ \\
\hline & & & & Statoil bygget - Tromsø & $55.3 \%$ \\
\hline & LEED & 9 & 1 & $\begin{array}{l}\text { Building Aviation Authority - } \\
\text { Bodø }\end{array}$ & Registered \\
\hline \multirow{3}{*}{ Sweden } & BREEAM-SE & 1174 & 0 & - & - \\
\hline & LEED & 292 & 1 & Hotel Kiruna - Kiruna & SILVER \\
\hline & Miljöbyggnad & 34 & 0 & - & - \\
\hline \multirow{4}{*}{ Finland } & \multirow[t]{2}{*}{ BREEAM } & \multirow[t]{2}{*}{445} & \multirow[t]{2}{*}{2} & $\begin{array}{c}\text { Ramboll Finland Oy - } \\
\text { Rovaniemi }\end{array}$ & $42.7 \%$ \\
\hline & & & & Koy Tornio - Tornio & $52.1 \%$ \\
\hline & LEED & 370 & 0 & - & - \\
\hline & RTS GLT & $\mathrm{n} / \mathrm{a}$ & $\mathrm{n} / \mathrm{a}$ & - & - \\
\hline \multirow{6}{*}{ Russia } & BREEAM & 138 & 0 & - & - \\
\hline & LEED & $\mathrm{n} / \mathrm{a}$ & $\mathrm{n} / \mathrm{a}$ & - & - \\
\hline & $\begin{array}{l}\text { GOST R } \\
54954\end{array}$ & $\mathrm{n} / \mathrm{a}$ & $\mathrm{n} / \mathrm{a}$ & - & - \\
\hline & Green & \multirow[b]{2}{*}{$\mathrm{n} / \mathrm{a}$} & \multirow[b]{2}{*}{$\mathrm{n} / \mathrm{a}$} & \multirow{3}{*}{-} & \\
\hline & $\begin{array}{c}\text { Standard } \\
\text { Certification } \\
\text { System }\end{array}$ & & & & - \\
\hline & Green Zoom & $\mathrm{n} / \mathrm{a}$ & $\mathrm{n} / \mathrm{a}$ & & - \\
\hline \multirow{11}{*}{ Canada } & \multirow{8}{*}{ LEED Canada } & \multirow{8}{*}{5448} & \multirow{8}{*}{8} & $\begin{array}{c}\text { Green Stone Building - } \\
\text { Yellowknife }\end{array}$ & GOLD \\
\hline & & & & $\begin{array}{l}\text { Yellowknife Gallery Office } \\
\text { Building - Yellowknife }\end{array}$ & SILVER \\
\hline & & & & $\begin{array}{c}38 \& 40 \text { Nijmegan Road - } \\
\text { Whitehorse }\end{array}$ & GOLD \\
\hline & & & & $\begin{array}{l}\text { FH Collins Secondary School } \\
\text { - Whitehorse }\end{array}$ & - \\
\hline & & & & 704 Wood Street - Whitehorse & PLATINUM \\
\hline & & & & 309 Main Street - Whitehorse & CERTIFIED \\
\hline & & & & $\begin{array}{c}\text { Whitehorse Hospital Staff } \\
\text { Residence -Whitehorse }\end{array}$ & SILVER \\
\hline & & & & $\begin{array}{l}\text { IQALUIT International Airport } \\
\text { Terminal Building }\end{array}$ & SILVER \\
\hline & BOMA Best & 2260 & 0 & - & - \\
\hline & LEED & 625 & 0 & - & - \\
\hline & $\begin{array}{l}\text { LEED for } \\
\text { Homes }\end{array}$ & 872 & 0 & - & - \\
\hline
\end{tabular}

reference. The evaluation considers eight categories of different weight and a final score of 100 , according to the following ranking: certified (40-49\%); silver (50-59\%); gold $(60-79 \%)$; platinum $(80-89 \%)$. Green Zoom is the most recently introduced Russian certification system. It is a LEED-based system evaluating 48 criteria, divided into nine categories, eight of which deal with the general performance of the building, and one with local climatic regional issues. Literature has not been found that provide information on the classification of the final score [33].

Unlike European Countries, BREEAM is not a popular rating tool in Canada. LEED, LEED for Homes and LEED Canada, a version meeting Canadian legislation and performance requirements, are the most widespread certifications. Along with these tools, the Building Owners and Manager Association Building Environmental Standards (BOMA best) releases five level of certifications: Certified ( $\geq 19 \%)$; Bronze ( $\geq 20 \%)$; Silver ( $\geq 50 \%$ ); Gold ( $\geq 80 \%$ ); Platinum ( $\geq 90 \%$ ); according to the following six areas: energy, water, waste reduction and site, emissions and effluents, indoor environment and environmental management system [34].

\subsection{Section Summary}

The Green Building Certification sector is lacking of a rating tool that take into consideration the specific arctic

\footnotetext{
* Corresponding author: 1.ravasio@uit.no
} 
conditions. Nevertheless, by analysing the set of criteria set by each of the currently used systems, the review has shown that there is no need to develop a different rating system. Due to an advanced technological level and economic possibilities of countries administering arcticregions, buildings in the Arctic are likely to satisfy each criteria and sub-criteria of any of the previously introduced rating system.

Even so, the evaluation could nonetheless be penalized according to the certification system being adopted. In fact, by analysing the criteria, it seems that BREEAM, LEED or Green Zoom place special emphasis on the Transport category, for which the evaluation considers the proximity to amenities and facilities of the building site. Since the Arctic consists mainly of rural areas, the constructions of buildings can be penalized by the Transport criteria and thus never achieve the maximum score.

Data presented in Table 1 also show the low number of certified buildings in the Arctic, compared to the entire country. According to numbers provided in the table, certified buildings in the arctic represents only the $1.59 \%$ of green buildings in Norway, for Finland, $0.24 \%$, for Canada, $0.085 \%$, for Sweden, $0.066 \%$, and the $0 \%$ for Russia.

\section{Benefits}

In literature, several studies have been completed that have extensively investigated the pros and cons associated with the development of Green buildings, as compared with conventionally constructed buildings. The benefits of Green Buildings cover environmental, economic and social aspects. Each of these is briefly discussed below.

From an environmental perspective, Green Buildings help to preserve the eco-system through a conscious and sustainable use of resources. This practice involves first, reduced use of energy and water, entailing a reduction of energy consumption and emissions, and second, pollution and waste reduction through reuse and recycling of materials for new buildings [35]. These benefits are also the result of requirements given by Green Building Assessment Tools regarding energy, waste and water consumption. Energy efficiency leads not only to higher performance compared to conventional buildings [44], but also to significant reductions of greenhouse gas emissions and other harmful air pollutants, whose release is associated with the combustion of fossil fuels for electricity and heat production [36].

Economic benefits result in cost savings due to the lower energy demand, thereby lowering operation and maintenance costs. In fact, on average, Green Buildings use $30 \%$ less energy than conventional buildings, owing to reduced electricity usage and as well, reductions in peak energy demand [37]. Although, meeting the requirements set out in Green Buildings standards require extra costs associated with construction materials, energy saving technologies and for the certification process. However, studies have shown that the investment is profitable given the energy savings and lower maintenance costs [38].
Technological innovations have played a key role in achieving these objectives and accreditations. Attaining the technical energy performance requirements for a building necessary affects the choice of act thermal insulation and energy generation systems. By ensuring optimal choice of insulation through the design of an advanced building envelope, energy losses during heating and cooling processes are limited, helping guaranty a stable building performance. Integration and utilization of renewable energy systems for energy generation also reduces energy consumption and emissions [39]. Despite the lack of infrastructure connecting electricity generated at the building site to the power grid, which is a common challenge when launching these technologies [26], there are several possibilities for exploiting new renewable energy resources in the Arctic. Norway, Sweden and Finland have already adopted integration of the grid with electricity produced by hydroelectric power plants, whereas Russia is running projects for energy generation, involving installation of photovoltaic panels and energy storage equipment in remote off-grid communities. Other innovative solutions include geothermal power and glacial meltwater power plants [40]. Especially in high energy-demand regions, such as the Arctic, acting on energy-saving measures to reduce consumption and costs during the life cycle of the building is a critical and fundamental aspect that cannot be overlooked.

Providing a high level of Indoor Environment Quality (IEQ) for Green Buildings is what ensures an occupant's improved health and productivity, as reflected in the higher level of comfort and performance in Green Buildings as compared to what is achieved in conventional buildings. This is provided by the integration of a mechanical ventilation system, that controls airflow and air quality, minimize sources of air pollution, and keeps the temperature at a comfortable level. Interior lighting quality, and building acoustics, contribute to the well-being of users [41]. However, studies have shown that difficulties in the control of temperature, ventilation and lighting inside the building often reduce the level of user's satisfaction [42].

Life cycle assessment (LCA) is another useful approach for analysing and bringing improvements to the technical aspects of Green Buildings. LCA focuses on many aspects, from manufacturing and transportation of materials, energy and water consumptions, to GHG emission during the operation stage. Through a correct analysis, LCA evaluates the impact of an entire building or a single component at an early stage, hence improving building design [43].

\section{Conclusions}

In this paper, a critical review of existing studies related to development of Green Buildings has been provided for five of the arctic countries. Even though there is an abundance of literature covering Green Buildings, the field is still lacking of studies specifically related to the Arctic region.

The review highlights the correlation between action plans for mitigating climate change in the Arctic, building 
legislation, and growth in popularity of sustainable constructions. Indeed, the adjustment of national building codes, along with arctic policies, to reduce building greenhouse gas emissions, are beneficial to the construction and housing sector as there is a push towards adopting sustainable solutions. Arctic countries are all cooperating and putting efforts and commitment into achieving common objectives.

In this process, Green Building rating tools play a key role. Setting standards and requirements, they are pushing boundaries of sustainability in the building sector. The evaluation process takes into consideration different parameters according to different climate conditions and geographical characteristics, making the tools reliable and versatile. Despite the small number of buildings certificated in the Arctic, the criteria considered by the different tools, showed the applicability of these systems in the Arctic. However, the review identified that transport criteria is a penalizing factor in the evaluation of green requirements.

Finally, the review highlights the general benefits and exposes criticalities of Green Buildings, focusing on the technologies needed for their development in the Arctic. In fact, the Arctic offers several solutions for green electricity generation. The challenge is creating a network that can reach rural areas, or alternatively, installing onsite production facilities. For this reason, it is necessary to develop technologies for on-site generation that can meet arctic requirements. To understand if Green Buildings located in the Arctic benefit from economic advantages, future research should also focus on arctic green building energy performance and cost analysis. In this way, it will be possible to calculate and estimate the average energy demand, energy savings and the related accomplishments in economic terms.

\section{References}

1. C.J. Kibert, Sustainable Construction: green building design and delivery (Jhon Wiley \& Sons Incorporated, 2016)

2. S. Kubba, Handbook of green building design and construction: LEED, BREEAM, and Green Globes (Elsevier Science, 2012)

3. Global Alliance for Buildings and Construction, 2019 Global Status Report for Buildings and Construction (IEA, 2019)

4. J. Yudelson, The Green Building Revolution (Island Press, 2008)

5. M.A.S. Akreim, O. Suzer, Env. Man. Sus. Dev. J., 7, 137 (2018)

6. R. Wang, X. Zhai, Handbook of Energy Systems in Green Buildings (Heidelberg: Springer Berlin Heidelberg, 2018)

7. AMAP, Arctic Climate Change Update 2019 (AMAP 2019)

8. X. Song, Sust. J, 9, 1605 (2017)

9. S.J. Hassol, Impacts of a Warming Arctic (Cambridge University Press, 2004)
10. Commission of the European Communities, Communication from the commission to the European Parliament and the Council (2008)

11. Government Offices of Sweden, Sweden's strategy for the Arctic Region (2014)

12. Norwegian Ministry of Foreign Affairs, New Building Blocks in the North (2009)

13. Norwegian Ministries, Norway's Arctic Strategy (2017)

14. Norwegian Ministry of Local Government and Regional Development, Building for the Future (2009)

15. Norwegian Ministry of the Environment, Norwegian Climate Policy (2011)

16. Swedish National Board of Housing, Building and Planning, Planning and Building Act, Planning and Building Ordinance (2010)

17. Government Offices of Sweden, Sweden's Seventh National Communication on Climate Change (2017)

18. Prime Minister of Finland, Finland's Strategy for the Arctic Region 2013 (2013)

19. Government of Finland, Finland, a land of solutions. Mid-term review. Government Action Plan 20172019 (2017)

20. Ministry of Employment of Finland, Energy and Climate Roadmap 2050 (2014)

21. UNECE, Energy efficiency requirements in buildings of Russian Federation (2018)

22. Government of Canada, Arctic and Northern Policy Framework International Chapter, https://www.rcaanccirnac.gc.ca/eng/1562867415721/1562867459588 (2019)

23. Government of Canada, Homes and Buildings https://www.canada.ca/en/services/environment/wea ther/climatechange/climate-action/federal-actionsclean-growth-economy/homes-buildings.html (2018)

24. Government of Canada, Advisory Council on Climate Action (2019)

25. World Green Building Council, About Green Building https://www.worldgbc.org/rating-tools (2019)

26. J. Zuo, Z. Zhao, Ren. Sus. En. Rev., 30, 271-281 (2014)

27. Z. Wu, L. Shen, Ann T.W. Yu, X. Zhang, Clen. Prod. J., 112, 895-902 (2016)

28. BREEAM, How BREEAM Certification Works https://www.breeam.com/discover/how-breeamcertification-works/ (2019)

29. Norwegian Green Building Council, BREEAM-NOR 2016 New Construction (2016)

30. Sweden Green Building Council - BREEAM-SE New Construction 2017 (2017)

31. Swedish Green Building Council, Certification https://www.sgbc.se/certifiering/ (2019) 
32. L. Sariola, The Building Information Foundation, RTS GLT Environmental Classification (2018)

33. K. Sokolov, Green Building Certification in Russia (Helsinki Metropolia University of Applied Science, 2016)

34. Boma Best Canada, Sustainable Buildings http://bomacanada.ca/bomabest/programs/\#sustaina ble-buildings (2019)

35. J. Heerwagen, Buil. Res. Info, 28, 353-367 (2000)

36. P. Macnaughton, X. Cao, J. Buonocore, J. CedenoLaurent, J. Spengler, A. Bernstein, J. Allen, Exp. Sci, Env. Epid. J., 28, 307 (2018)

37. Gregory H. Kats, Green Building Costs and Financial Benefits (2003)

38. H. Gabay, Isaac A. Meir, M. Schwarts, E. Werzberger, En. Buil. J., 76, 558-564 (2014)

39. Wen X. Ding, Yu H. Zhao, X. Ji, App. Mec. Mat. J., 368, 1135-1138 (2013)

40. G. Arruda, Renewable Energy for the Arctic: New Perspectives (Routledge, 2019)

41. A. Leaman, B. Bordass, Buil. Res. Inf. J., 35, 662673 (2007)

42. S. Abbaszadeh, L. Zagreus, D. Lehrer, C. Huizenga, Eight international conference for healthy buildings 2006: creating an healthy environment for people (2006)

43. Sami G. Al-Ghamdi, Melissa M. Bilec, Arch. Eng. J., 23 (2017) 